\title{
Article
}

\section{Endophytic fungi associated with bamboo as possible sources of single cell protein using corn cob as a substrate}

\author{
Paynor KA ${ }^{1}$, David ES ${ }^{1}$ and Valentino MJG ${ }^{1^{*}}$ \\ ${ }^{I}$ Department of Biological Sciences, College of Arts and Sciences, Central Luzon State University, Science City of \\ Munoz, Nueva Ecija, 3120 Philippines
}

Paynor KA, David ES, Valentino MJG 2016 - Endophytic fungi associated with bamboo as possible sources of single cell protein using corn cob as a substrate. Mycosphere 7(2), 139-147, Doi 10.5943/mycosphere/7/2/5

\begin{abstract}
This study was undertaken to determine the potential of nine endophytic fungi associated with bamboo namely: Cladosporium cladosporioides, Aspergillus ochraceus, Aspergillus niger, Aspergillus flavus, Penicillium citrinum, Monascus ruber, Fusarium semitectum, Fusarium sp. 1 and Fusarium sp. 2 as sources of single cell protein. In addition, proximate composition of the fungal enriched corn cob which includes moisture, ash, crude fat and crude fiber were also determined. Lastly, cytotoxicity of the treated corn cob was also evaluated to determine their feasibility as safe substitute to animal feeds.

Results of the study revealed that inoculation of endophytic fungi could enhance the proximate composition of corn cob. Cladosporium cladosporioides - treated corn cob obtained the highest crude protein content (CPC) of 3.23\%, while, Aspergillus niger - treated corn cob registered the least CPC of $2.51 \%$. For the percentage increase CPC, Cladosporium Cladosporioides - treated corn cob registered the highest percentage increase of $13.64 \%$. For the moisture content, Fusarium sp. 2 - treated corn cob obtained the highest moisture content with $2.45 \%$, while the uninoculated corn cob had the lowest moisture of $1.48 \%$. For the ash content, Penicillium citrinum - treated corn cob obtained the highest $\%$ ash with $2.94 \%$ while A. ochraceus - treated corn cob had the least $\%$ ash of 2.25. For the crude fat, Fusarium sp. 1 - treated corn cob obtained the highest crude fat of $0.76 \%$ while the Aspergillus ochraceus, Cladosporium cladosporioides and Penicillium citrinum - treated corn cob obtained the least crude fat of $0 \%$. For the crude fiber, Fusarium sp. 1 - treated corn cob recorded the highest crude fiber with $33.09 \%$ while the uninoculated corn cob with $30.93 \%$ had the least crude fiber content. For the cytotoxicity test, 3.33\% mortality rate was recorded after 6 hours of incubation as observed in Aspergillus niger, Fusarium semitectum and Fusarium sp. 1 - treated corn cob. At 12 hours of incubation, Fusarium semitectum had the highest mortality rate of $6.67 \%$. Lastly, after 18 hours and 24 hours of incubation, 3.33\% mortality rate was observed in Fusarium sp. 1 and Aspergillus flavus - treated corn cob.
\end{abstract}

Key words - corn cob - crude protein content - endophytes - fungi - single cell protein - solid state fermentation

\section{Introduction}

In the Philippines, Zea mays L. (corn) is second to rice as the most important crop with an 
annual production of approximately 4 million tons of grain corn leading to about 0.96 million tons of corn cobs (Zafar 2015). The corn cob carries the grain and together with associating husks, shanks and silks are harvested from the farm, wherein it can be utilized as animal feeds and biofertilizer (Kludze et al. 2010). Corn-cob is agricultural by products rich in cellulosic fibers and poor in protein (Alkhazraji et al. 2012). The recent study of Ashour et al. (2013) revealed the presence of eight phytochemical compounds in corncobs which includes two phenylpropanoids, two flavonoids and four plant sterols. In addition, corn cob is high in its cellulosic content, but is low in protein. It contains $39.1 \%$ cellulose, $42.1 \%$ hemicellulose, $9.1 \%$ lignin, $1.7 \%$ protein, and $1.2 \%$ ash (Barl et al. 1991). Moreover, agricultural wastes are known to support the growth of microorganism as single cell protein and thus enhance feed quality (Sharma \& Arora 2013; Anupama \& Ravindra 2001, Anumapa 2000).

Single cell protein (SCP) or microbial protein is the dried biomass of microorganisms such as bacteria, fungi or algae grown in different substrates such as whey, starch, cellulose, alcohols and molasses (Nasseri et al. 2011, Yakoub Khan \& Umar Dahot 2010, Esabi 2001). As a source of protein, it is very promising with the potential to satisfy the world shortage of food as populations increase (Najafpour 2007). Single cell protein (SCP) is used as protein sources in human foods and animal feeds (Kurbanoglu 2001). Its composition varies based upon the organism and the substrate which it grows. Basically it comprises protein, fats carbohydrates, ash ingredients, water and other elements such as phosphorous and potassium which (Faust 1997).

Plant endophytic fungi are fungal organisms colonizing the plant tissue without causing any symptoms or injury to the plant and about one million fungi have been existing in nature (Petrini 1991; Hyde \& Soytong 2008). Their importance as sources of novel and important bioactive products in agriculture, medicine and food industry had already been proven (Verma et al. 2009, Gunatilaka 2006, Strobel et al. 2004). However, little has been reported on their ability to produce single cell protein. Hence, the use of corn cob as substrate for single cell protein production of the endophytic fungi associated with bamboo.

\section{Materials \& Methods}

Methodology was adapted from the previous work of Valentino et al. (2015) with some modifications. Pure culture of endophytic fungi was obtained from the collection of Mary Jhane G. Valentino at the Department of Biological, Sciences, Science City of Munoz, Nueva Ecija, Philippines.

\section{Preparation of the inoculum}

Inoculum was prepared by growing endophytic fungi in PDA for 7 days. Then, $60 \mathrm{ml}$ of sterile water was added to the cultures and it was adjusted to $5 \times 10^{6}$ cells per $\mathrm{ml}$ using haemocytometer.

\section{Preparation of substrates}

Corn cobs were collected from Seed Center, Science City of Munoz, Nueva Ecija, Philippines. It was sun dried and pulverized into powdered form. Ground corn cob was analyzed for its Crude Protein Content (CPC) using Kjeldahl method. This CPC served as the initial CPC of the substrate. One hundred (100) grams of dried corn cob were placed in a clean bottle and $200 \mathrm{ml}$ of distilled water was added to the substrate. These were then covered with plastic and were sterilized at $15 \mathrm{psi}$ at $121^{\circ} \mathrm{C}$ for one hour.

\section{Inoculation of fungal endophytes in corn cob}

Twenty (20) $\mathrm{ml}$ of the adjusted spore suspension of different fungal endophytes were aseptically transferred to the substrate and were covered with plastic. The inoculum was allowed to acclimatize in the substrate for 20 days at room temperature. 


\section{Harvesting and drying}

After 20 days of solid state fermentation, the cultures were sterilized at 15 psi for 30 minutes. Harvested samples were oven dried for two days. Dried samples were pulverized using mortar and pestle. Dried and pulverized samples were analyzed for the crude protein content (CPC) using Kjeldahl method.

\section{Proximate composition}

Ground corn cob (250 g) was sent to Lipa Quality Control Center - Bocaue, Bulacan, Philipines for proximate analysis of the nutritional content such as crude protein, crude fat, crude fiber, moisture and ash content. Moisture content, ash content, crude fat, crude carbohydrates, crude protein and total energy value was based on the guidelines of the Association of Official Analytical Chemist (1995).

\section{Cytotoxicity of fungal enriched corn cob}

\section{Brine shrimp hatchery set up}

The hatchery vessel was made using a translucent $1.5 \mathrm{~L}$ soft drink plastic bottle wherein the base was cut and hung in the hatchery rack upside-down or vessel like. The aerator (aquarium air pump) was connected to the hatchery by creating a hole in the hatchery cap and inserting the air pump rubber tubing inside. An air stone was attached at the tip of the tubing inside the hatchery to maintain a temperature of $28-30^{\circ} \mathrm{C}$, an eighteen (18) - watt fluorescent bulb was placed about 12 inches above the hatchery vessel.

\section{Hatching of brine shrimp eggs}

ARTEMIA HIGH5 brine shrimp eggs were acquired from the Ulang Production of the Crustacean Section, Bureau of Fisheries and Aquatic Resources, Science City of Munoz, Nueva Ecija, Philippines.

The hatchery was filled with saline solution made by mixing sea salt or rock salt to sterilized water with the proportion of $30 \mathrm{~g}$ of salt for every $1000 \mathrm{ml}$ of water. One gram of ARTEMIA HIGH5 brine shrimp eggs was hatched in the saline solution within 48 hours under illumination and with adequate aeration to keep the eggs in suspension until its 48 hours life. The hatchery was covered with thin gauze for protection against the entrance of undesirable insects and other small animals that may be harmful to the developing eggs. The hatched eggs produced larvae called the nauplii. The nauplii were used for the assay.

\section{Cytotoxicity assay}

Using hand lens, active $48 \mathrm{hr}$ old nauplii were harvested and used for the assay. Ten nauplii were transferred into a saline solution. Ten milligram of each treatment was added to $5 \mathrm{ml}$ saline solution which served as the brine shrimp food. Living nauplii were counted at 6,12, 18 and 24 hours. The mortality of the brine shrimp was computed using the Abbot's mortality formula.

\section{Results and Discussion}

This study was conducted to determine the ability of nine endophytic fungi associated with bamboo namely; Cladosporium cladosporioides, Aspergillus ochraceus, Aspergillus niger, Aspergillus flavus, Penicillium citrinum, Monascus ruber, Fusarium semitectum, Fusarium sp. 1 and Fusarium sp. 2 in the production of single cell protein by increasing the crude protein content and enhancing the proximate composition of the fungal enriched corn cob. Cytotoxicity test using brine shrimp was also undertaken to determine the toxicity of the fungal enriched corn cob as substitute to yeast as feeds. 


\section{Production of Single Cell Protein}

Single cell protein potential of the nine endophytic fungi associated with bamboo was determined through crude protein content analysis. In addition, proximate composition of the protein enriched corn cob which include ash, moisture, crude fat and crude fiber content were also determined.

Percentage increase in crude protein content was evaluated. Table 1 presents the crude protein content (CPC) of corn cob and their corresponding percentage increase in CPC. Results showed that Cladosporium cladosporioides - treated corn cob obtained the highest percentage CPC of $3.23 \%$, followed by Fusarium sp. 2 - treated corn cob with $3.19 \%$ and Monascus ruber - treated corn cob with 3.14\%. On the other hand, Aspergillus niger - treated corn cob registered the least CPC of $2.51 \%$ followed by Aspergillus ochraceus - treated corn cob of $2.71 \%$ which is noticeably lower than the uninoculated corn cob with CPC of $2.86 \%$. While for the percentage increase CPC, Cladosporium cladosporioides, Fusarium sp. 2 and Monascus ruber - treated corn cob registered the highest percentage increase of $13.64 \%, 11.54 \%$ and $9.68 \%$, respectively.

Statistical analysis for the CPC of the fungal enriched corn cob revealed that among all the treatment means, only Cladosporium cladosporioides - treated corn cob is significantly higher from the uninoculated corn cob. This indicates that among all the nine endophytic fungi used, only the Cladosporium cladosporoides has the potential of increasing the CPC of corn cob, thus could be a possible source of single cell protein.

Table 1 Mean percentage of crude protein composition of fungal enriched corn cob

\begin{tabular}{llc}
\multicolumn{1}{c}{ Treatments } & Crude Protein & \% increase in Crude Protein \\
\hline Uninoculated Corn cob & $2.86^{\mathrm{abc}}$ & $8.86^{\mathrm{ab}}$ \\
Aspergillus flavus - treated corn cob & $3.11^{\mathrm{cd}}$ & $0^{\mathrm{a}}$ \\
Aspergillus niger - treated corn cob & $2.54^{\mathrm{a}}$ & $0^{\mathrm{a}}$ \\
Aspergillus ochraceus - treated corn cob & $2.71^{\mathrm{ab}}$ & $13.64^{\mathrm{b}}$ \\
Clasdosporium cladosporioides - treated corn cob & $3.23^{\mathrm{d}}$ & $9.68^{\mathrm{ab}}$ \\
Monascus ruber - treated corn cob & $3.14^{\mathrm{cd}}$ & $7.33^{\mathrm{ab}}$ \\
Penicillium citrinum - treated corn cob & $2.98^{\mathrm{bcd}}$ & $8.63^{\mathrm{ab}}$ \\
Fusarium semitectum - treated corn cob & $3.11^{\mathrm{cd}}$ & $4.66^{\mathrm{ab}}$ \\
Fusarium sp. 1 - treated corn cob & $2.99^{\mathrm{bcd}}$ & $11.54^{\mathrm{ab}}$ \\
Fusarium sp. 2 - treated corn cob & $3.19^{\mathrm{cd}}$ &
\end{tabular}

Inability of the Aspergillus niger, Aspergillus flavus, Aspergillus ochraceus, Monascus ruber, Penicillium citrinum, Fusarium semitectum, Fusarium sp 1 and Fusarium sp 2 to enhance the CPC can be due to nutritional attributes and lignocellulosic composition of the substrate. The cellulose, hemicellulose and lignin components of corn cob were found to be very resistant to enzymatic degradation which could greatly affect the enzymatic activity of the endophytic fungi (Menon \& Rao 2012, Javed Asad et al. 2000). In addition, Javed Asad et al. (2000) reported that corn cob cannot be utilized efficiently by microbes without pre-treatment. Accordingly, Orzuaa et al. (2009) revealed that the most suitable solid support for A. niger (with the lowest CPC) were lemon peel, orange peel, apple pomace, pistachio shell, wheat bran, coconut husk, pecan nutshell, creosote bush leaves and bean residues.

Contrary to the results of the CPC analysis, several reports had indicated the ability of fungi in enhancing the crude protein content of several agro industrial wastes by secreting enzymes such as amylase and cellulose (Oboh \& Akindahunsi 2003, Akindahunsi et al. 1999). Likewise, most agricultural wastes are known to support the growth of microorganism thereby synthesizing hydrolytic co-enzymes and proteases during fermentation, which results in metabolic reactions that hydrolyze cellulose to glucose (Lohlum et al. 2014, Sharma \& Arora 2013, Sanusi et al. 2013, Erukainure et al. 2010). In addition, the cell growth of fungi causes the breakdown of polysaccharides 
and release of bound proteins thereby increasing the protein content and making the substrate nutritionally better (Belewu et al. 2005).

Cladosporium cladosporioides can be used to enhance the CPC as compared to the other endophytes. Cladosporium cladosporioides produced xylanase at a rapid rate. As with other studies, the level of xylanase production was related to the growth of the cells (Ko et al. 2010). Xylanase extracts may be incorporated as ruminant feed additives, to improve ruminant fiber digestion resulting in increased digestible energy intake (Giraldo et al. 2008, Pinos-Rodriguez et al. 2002). Similar results were also described by Ugwuanyi et al. (2008), with protein enrichment of corncob heteroxylan waste slurry by thermophilic aerobic digestion. Protein enrichment might be due to the secretion of enzymes such as cellulase, phytase, and xylanase during the growth of microbes to convert the fiber materials formonosaccharide Ugwuanyi et al. (2008). In addition, some authors reported that, the colonization of wastes by fungi results in increase in their nutritional values (Zadrazil 1993; Belewu \& Okhawere 1998).

\section{Proximate Composition}

Proximate composition of the untreated and treated corn cob which include moisture, ash, crude fat and crude fiber were presented in Table 2.

Table 2 Mean percentage of proximate composition of enriched corn cob

\begin{tabular}{lcccc}
\hline \multicolumn{1}{c}{ Treatments } & Moisture & Ash & $\begin{array}{c}\text { Crude } \\
\text { Fat }\end{array}$ & $\begin{array}{c}\text { Crude } \\
\text { Fiber }\end{array}$ \\
\hline Uninoculated Corn cob & $1.48^{\mathrm{a}}$ & $2.26^{\mathrm{a}}$ & $0.61^{\mathrm{b}}$ & $30.93^{\mathrm{a}}$ \\
Aspergillus flavus -treated corn cob & $1.86^{\mathrm{ab}}$ & $2.58^{\mathrm{cd}}$ & $0.31^{\mathrm{ab}}$ & $32.22^{\mathrm{ab}}$ \\
Aspergillus niger -treated corn cob & $2.16^{\mathrm{bc}}$ & $2.41^{\mathrm{b}}$ & $0.38^{\mathrm{ab}}$ & $31.77^{\mathrm{ab}}$ \\
Aspergillus ochraceus -treated corn cob & $1.64^{\mathrm{a}}$ & $2.25^{\mathrm{a}}$ & $0.00^{\mathrm{a}}$ & $32.21^{\mathrm{ab}}$ \\
Clasdosporium cladosporioides-treated cob & $1.78^{\mathrm{ab}}$ & $2.86^{\mathrm{ef}}$ & $0.00^{\mathrm{a}}$ & $31.99^{\mathrm{ab}}$ \\
Monascus ruber -treated corn cob & $1.88^{\mathrm{ab}}$ & $2.69^{\mathrm{d}}$ & $0.38^{\mathrm{ab}}$ & $32.84^{\mathrm{b}}$ \\
Penicillium citrinum-treated corn cob & $1.74^{\mathrm{ab}}$ & $2.94^{\mathrm{f}}$ & $0.45^{\mathrm{ab}}$ & $31.14^{\mathrm{a}}$ \\
Fusarium semitectum-treated corn cob & $1.86^{\mathrm{ab}}$ & $2.48^{\mathrm{bc}}$ & $0.00^{\mathrm{a}}$ & $31.06^{\mathrm{a}}$ \\
Fusarium sp. 1 -treated corn cob & $1.86^{\mathrm{ab}}$ & $2.81^{\mathrm{e}}$ & $0.76^{\mathrm{b}}$ & $33.09^{\mathrm{b}}$ \\
Fusarium sp. 2 -treated corn cob & $2.45^{\mathrm{bc}}$ & $2.59^{\mathrm{cd}}$ & $0.70^{\mathrm{b}}$ & $31.13^{\mathrm{a}}$ \\
\hline
\end{tabular}

*Treatments with the same letters are not significantly different

\section{Moisture}

As presented in Table 2, Fusarium sp. 2 - treated corn cob obtained the highest moisture content with $2.45 \%$. The uninoculated corn cob with $1.48 \%$ had the lowest moisture percentage followed by the Aspergillus ochraceus - treated corn cob with $1.64 \%$. Statistical analysis revealed that the moisture content of Aspergillus niger and Fusarium sp. 2 - treated corn cob were significantly higher compared to all treatments used.

The moisture in solid-state fermentation can influence the synthesis and secretion of extracellular enzymes reducing the porosity of the medium, interfering with the gas transfer and temperature. On the other hand, the low moisture content can decrease the solubility of nutrients, disfavoring microbial metabolic activity (Ellaiah et al. 2002). On the hand, further increase in moisture can lead to a decrease in enzyme production.

\section{Ash}

Ash content indicates the presence of organic matter corn cob. As presented in Table 2, Penicillium citrinum - treated corn cob obtained the highest $\%$ ash with $2.94 \%$ followed by Cladosporium cladosporioides - treated corn cob and Fusarium sp 1 - treated corn cob with $2.86 \%$ and $2.81 \%$, respectively. On the other hand, Aspergillus ochraceus - treated corn cob had 
the least of $2.25 \%$ followed by the uninoculated corn cob with $2.26 \%$. Results of statistical analysis also suggest that $\%$ ash of the eight endophytic fungi treated corn cob were significantly higher than the Aspergillus ochraceus - treated corn cob and the uninoculated corn cob. Thus, endophytic fungi contribute to the increase of ash percentage of the corn cob. This could be due to the fermentation of the fungal endophytes indicating their biosynthetic or hydrolytic mechanisms to increase the inorganic mineral elements in the treated corn cob (Oladele \& Oshodi 2008, Oseni \& Ekperigin 2007). Results also conform to the findings of Sanusi et al. (2013) and Adeyemi et al. (2012) wherein an observable increase ash contents of the fermented seeds of Jatropha and Sassafras albidum seeds were noted using various cultures of fungi.

\section{Crude fat}

For the evaluation of crude fat percentage, as shown in Table 2, Fusarium sp. 1 - treated corn cob obtained the highest crude fat of $0.76 \%$ followed by Fusarium sp. 2 and uninoculated corn cob with $0.70 \%$ and $0.61 \% \%$, respectively. Aspergillus ochraceus, Cladosporium cladosporioides and Fusarium semitectum - treated corn cob had the least crude fat of $0.00 \%$. Statistical analysis also revealed that Aspergillus ochraceus, Cladosporium cladosporioides and Fusarium semitectum - treated corn cob were significantly lower than the uninoculated corn cob and all the remaining treatments, thus, enhancing the quality of the corn cob as animal feeds since low animal feeds with lower crude fat is more desirable.

Consequently, the general low lipid content of the fermented sample could enhance its usefulness as animal feed because high fat content in feed ingredients could cause difficulty in mixing the feed and it also require antioxidants for preventing the feed from oxidative rancidity (Emiola et al. 2007). The increase in fat content of the fungal fermented sample could be due to the possibility of the fermenting fungi to transform the carbohydrate content of the seeds to fat (Esabi, 2001). Besides, some fungi have been reported to synthesize microbial oil during fermentation (Oboh \& Akindahunsi 2003). It has also been reported that fungi have more lipogenic ability than lipolytic ability which could enhance ether extract content of the fungi treated sample (Sanusi et al. 2013). Also, fat is important in diets because it promotes fat soluble vitamin absorption (Bogert et al. 1994, Raphael et al. 2010). Increase in lipid content in A. niger due to its ability to synthesize long chain fatty acids from acetyl coenzymes A and other complex unsaturated lipids, Iyayi and Aderolu (2004).

\section{Crude fiber}

For crude fiber percentage, Fusarium sp 1 - treated corn cob recorded the highest crude fiber with 33.09\% followed by Monascus ruber with 32.84\% and Aspergillus flavus - treated corn cob with $32.22 \%$, respectively. The least crude fiber content was observed in uninoculated corn cob with $30.93 \%$ and Fusarium semitectum with $31.06 \%$. Statistical analysis showed that Fusarium sp. 1 and $M$. ruber - treated corn cob was significantly higher that the uninoculated corn cob while the rest are comparable to the uninoculated rice bran. This indicates the ability of the aforementioned endophytic fungi in increasing the crude fiber content of the corn cob.

Based on the results the crude fiber of the fermented residue was higher than the unfermented sample. Perez-Hidalgo et al. (1997) proposed that the formation of resistant starch together with condensed tannin-protein complex could contribute to the increase. This may also be responsible for the high tannin content of the fermented sample which is within the accepted save level, while the phytate (which is capable of chelating divalent cationic minerals like $\mathrm{Ca}, \mathrm{Fe}, \mathrm{Mg}$ and $\mathrm{Zn}$, thereby inducing dietary deficiency) content of the fermented sample was reduced as a result of fermentation (Shakuntalamanay \& Shadaksharaswamy 1987).

\section{Cytotoxicity of the fungal enriched corn cob}

The cytotoxicity of the endophytic fungi-treated corn cob and the uninoculated corn cob was determined to assess their feasibility as possible substitute to animal feeds. 
As shown in Table 3, at all incubation period, a very low to 0 mortality rate was recorded. At 6 hours of incubation, mortality rate of 3.33\% was observed in Aspergillus niger, Fusarium semitectum and Fusarium sp. 1 - treated corn cob. While at 12 hours of incubation, F. semitectum had the highest mortality rate of $6.67 \%$ followed by Aspergillus niger, Fusarium sp. 1 and uninoculated corn cob of 3.33\%. Finally, after 18 hours and 24 hours of incubation, 3.33\% mortality rate was observed in Fusarium sp. 1 and Aspergillus flavus - treated corn cob. Statistical analysis revealed no significant difference among all the treatments means. This suggests the fungi used and not cytotoxic and can be use as substitute to animal feeds.

Table 3 Mean percentage of brine shrimp mortality

\begin{tabular}{|c|c|c|c|c|}
\hline Treatment & $6 \mathrm{hrs}$ & 12 hrs & 18 hrs & 24 hrs \\
\hline Uninoculated Corn cob & $0.00^{\mathrm{a}}$ & $3.33^{\mathrm{a}}$ & $0.00^{\mathrm{a}}$ & $0.00^{\mathrm{a}}$ \\
\hline Aspergillus flavus - treated corn cob & $3.33^{\mathrm{a}}$ & $3.33^{\mathrm{a}}$ & $0.00^{\mathrm{a}}$ & $0.00^{\mathrm{a}}$ \\
\hline Aspergillus niger - treated corn cob & $3.33^{\mathrm{a}}$ & $6.67^{\mathrm{a}}$ & $0.00^{\mathrm{a}}$ & $0.00^{\mathrm{a}}$ \\
\hline Aspergillus ochraceus - treated corn cob & $3.33^{\mathrm{a}}$ & $3.33^{\mathrm{a}}$ & $3.33^{\mathrm{a}}$ & $3.33^{\mathrm{a}}$ \\
\hline Clasdosporium cladosporioides - treated corn cob & $0.00^{\mathrm{a}}$ & $0.00^{\mathrm{a}}$ & $0.00^{\mathrm{a}}$ & $0.00^{\mathrm{a}}$ \\
\hline Monascus ruber - treated corn cob & $0.00^{\mathrm{a}}$ & $0.00^{\mathrm{a}}$ & $0.00^{\mathrm{a}}$ & $0.00^{\mathrm{a}}$ \\
\hline Penicillium citrinum - treated corn cob & $0.00^{\mathrm{a}}$ & $0.00^{\mathrm{a}}$ & $0.00^{\mathrm{a}}$ & $0.00^{\mathrm{a}}$ \\
\hline Fusarium semitectum - treated corn cob & $0.00^{\mathrm{a}}$ & $0.00^{\mathrm{a}}$ & $3.33^{\mathrm{a}}$ & $3.33^{\mathrm{a}}$ \\
\hline Fusarium $\mathrm{sp} 1$ - treated corn cob & $0.00^{\mathrm{a}}$ & $0.00^{\mathrm{a}}$ & $0.00^{\mathrm{a}}$ & $0.00^{\mathrm{a}}$ \\
\hline Fusarium sp 2 - treated corn cob & $0.00^{\mathrm{a}}$ & $0.00^{\mathrm{a}}$ & $0.00^{\mathrm{a}}$ & $0.00^{\mathrm{a}}$ \\
\hline
\end{tabular}

* Treatment means with the same letter are not significantly different

The results of the study proved the ability of the endophytic fungi associated with bamboo in enhancing the proximate composition and increasing the crude protein content of corn cob, therefore its utilization as an alternative to expensive animal feeds.

\section{Acknowledgements}

To God be the Glory! Thy will be done.

\section{References}

Abdoljabbar Alkhazraji A, AL-Maadhidi JF, Abu Tabigh S. 2012 - Effect of biological treated corn cobs in Growth, Some Hematological and Biochemical Aspects in Awassi Male Lambs. 2nd International Conference on Environment Science and Biotechnology IPCBEE, 48.

Adeyemi, IA, Umar S. 1994 - Effect of method of manufacture on quality characteristics of kunun-zaki, a millet-based beverage. Nigerian Food Journal 12, 34-41.

Akindahunsi AA, Oboh G, Oshodi AA (1999). Effect of fermenting cassava with Rhizopus oryzae on the chemical Composition of its flour and gari. La Rivista Italiana Delle Sostanze Grasse, 76: 437-440.

Al-maadhidi JF, AL-khatib MT. 2010 - Digestion of fiber and increased crude protein in corncobs. Journal of Madenat Alelem College 2, 28-29.

Anumapa, P. 2000 - Value-added food: Single cell protein. Biotechnology Advances. Pineknoll Publishing P.O. Box 6, Keedysvill, Md 21756.

Anupama, Ravindra P. 2001 - Studies on production of single cell protein by Aspergillus niger in solid state fermentation of rice bran. Brazilian Archives of Biology and Technology, 44(1).

Ashour A, Amer M, Marzouk A, Shimizu K, Kondo R, El-Sharkawy S. 2013 - Corncobs as a potential source of functional chemicals. Molecules 18, 13823-13830.

Association of Official Analytical Chemists. 1995 - Official Methods of Analysis of the Association of Official Analytical Chemists, 16th edition, Arlington, USA. 
Barl B, Biliaderis C, Murray, E, Macgregor, A. 1991 - Combined chemical and enzymatic treatments of corn husks lignocellulosics. J. Sci. Food Agric., 56, 195-214.

Belewu MA, Belewu KY. 2005 - Cultivation of Mushroom (Volvariella volvacea) on Banana leaves. African Journal of Biotechnology 4(1): 1402-1401

Belewu MA, Okhawere OC. 1998 - Evaluation of Feeding Fungi Treated Rice Husk to Ram. In Proceeding of the 25th Annual Conference and Silver Jubilee of the Nigerian Society Animal Production. 321- 322.

Bogert, JL, Briggs GM , Galloway DH. 1994 - Nutrition and physical fitness. Int. J. Food Sci. Nutr. 45, 223-230.

Ellaiah P, Adinaraya K, Bhavani Y, Padmaya P. Srinivasulu. 2002 - Optimization of process parameters for glucoamylase production under solid state fermentation by a newly isolated Aspergillus species. Process Biochem 38, 615-620.

Emiola IA, Ologhobo AD, Gous RM. 2007 - Performance and histological responses of internal organs of broiler chickens fed raw, dehulled, and aqueous and dry-heated kidney bean meals. Poultry Sci. 86, 1234-1240.

Erukainure O, Oke OO, DAramola AO, Adenekan SO, Umanhonlen EE. 2010 - Improvement of the biochemical properties of watermelon rinds subjected to Saccharomyces cerevisiae solid substrate fermentation Pak. J. Nutri. 9(8), 806 - 8092.

Esabi BK. 2001 - Production of single cell protein from Ram horn hydrolysate. Turk. J. Biol. 25, $371-377$.

Faust U. 1997 - Production of microbial biomass. In: Prave P, Faust U, Sitting, W. (eds). Fundamentals of Biotechnology. Weinhelm: VCH Publishers.

Giraldo LA, Tejido ML, Ranilla MJ, Ramos S, Carro MD. 2008 - Influence of direct-fed fibrolytic enzymes on diet digestibility and ruminal activity in sheep fed a grass hay-based diet. Journal of Animal Science, 86 (7), 1617 - 1623

Gunatilaka AAL. 2006 - Natural products from plant-associated microorganisms: distribution, structural diversity, bioactivity, and implications of their occurrence. Journal of Natural Products 69, 505-526.

Hyde KD, Soytong K. 2008 - The fungal endophyte dilemma. Fungal Diversity 33: 163-173. Iyayi EA, Aderolu ZA. 2004 - Enhancement of Loss of Feeding Value of some agro - industrial by- Products for Laying Hens After their Solid State Fermentation with Trichoderma viride. Journal of Biotechnology 3(3), 182-185.

Iyayi EA, Aderolu AZ. 2004 - Enhancement of the feeding values of some agro- industrial byproducts for laying hens after their solid state fermentation with Trichoderma viride. Afr. J. Biotech. 3, $182-185$.

Javed Asad M, Asghar M, Yaqub M, Shahzad K. 2000 - Production of single cell protein from delignified corn cob by Arachniotus species. Pak. J. Agri . Sci. tot. 37, 3-4.

Jecu L 2000. Solid-state fermentation of agricultural wastes for endoglucanase production. Ind. Crop. Prod. 11, 1-5.

Kludze H, Deen B, Weersink A, van Acker R, Janovicek K, De Laporte A. 2011 - Assessment of the availability of agricultural biomass for heat and energy production in Ontario. 01.27

Ko CH, Lin ZP, Tu J, Tsai CH, Liu CC, Chen HT, Wang TP. 2010. Xylanase production by Paenibacillus campinasensis BL11 and its pretreatment of hardwood kraft pulp bleaching. Int Biodeterior Biodegradation 64, 13-9.

Kurbanoglu E. 2001 - Production of single cell protein from Ram horn hydrolysate. Turk. J. Biol., 25: $371-377$.

Lohlum SA, Forcados EG, Chuku A, Agida OG, Ozele N. 2014 - Corn cob as feed component through fungal fermentation using Aspergillus niger. CIBTech Journal of Microbiology 3(2), 37-42.

Maina JG, Beames RM, Higgs D, Mbugua PN, Iwama G, Kisia SM. 2007 - The feeding value and protein quality in high-fibre and fibre-reduced sunflower cakes and Kenya's "omena" 
fishmeal for tilapia (Oreochromis niloticus). Livestock Research for Rural Development 19, 164.

Menon V, Rao M. 2012 - Trends in bioconversion of lignocellulose: Biofuels, platform chemicals \& biorefinery concept. Progress in Energy and Combustion Science 38(4), 522-550.

Najafpour, Ghasem D. 2007 - Single Cell Protein. BiochemicalEngineering and Biotechnology : 332-341.

Nasseri AT, Rasoul-Amini S, Morowvat MH, Ghasemi Y. 2011 - Single cell protein: Production and process. American Journal of Food Technology 6(2), 103-116.

Oboh G, Akindahunsi AA. 2003 - Biochemical changes in Cassava products (flour \& gari) subjected to Saccharomyces cerevisae solid media fermentation. Food Chem. 82(4), 599602.

Oladele EP, Oshodi AA. 2008 - Effect of fermentation on some chemical and nutritive properties of berlandier nuttle spurge ad physic nut seeds, Pak. J. Nutr. 7, 292-296.

Orzuaa MC, Mussatto SI, Esquivel JC, Rodriguez R, Dela Garzaa H, Teixeira JA, Aguilar CN. 2009 - Industrial Crops and Products 30, $24-27$.

Oseni OA, Ekperigin M. 2007 - Studies on the biochemical changes in maize wastes fermented with Aspergillus niger. Biokemistri 19, 75-79.

Perez-Hidalgo MA, Guerra-Hernendez E, Garcia-Villanova B. 1997 - Dietary Fiber in three raw legumes and processing Effect on Chick Peas by an Enzymatic-Gravimetric method. J. of Food Composition and Analysis 10, 66-72.

Petrini O. 1991 - Fungal endophytes of tree leaves. In: Andrews JH, Hirano SS, eds. Microbial Ecology of Leaves. New York: Spring Verlag 179-197.

Pinos - Rodriguez JM, Gonzalez SS, Mendoza GD, Barcena R, Cobos MA, Hernandez A, Ortega ME. 2002 - Effect of exogenous fibrolytic enzyme on ruminal fermentation and digestibility of alfalfa and rye-grass hay fed to lambs. Journal of Animal Science 80(11). 3016-3020.

Raphael EC, Gideon OI, Nwachukwu U, Perpetua NU. 2010 - Biochemical Characteristics of the African Nutmeg, Monodora myristica. Agricultural Journal 5(5), 303-308.

Sanusi GO, Belewu MA, Oduguwa BO. 2013 - Changes in chemical composition of Jatropha curcas kernel cake after solid-state fermentation using some selected fungi. Global J. Biol. Agric. Health Sci. 2(2), 62-66.

Shakuntalamanay N, Shadaksharaswamy M. 1987 - Food Facts and Principle, Published by Mohinder Singh Sejwal for Wiley Eastern Limited, New Delhi India.

Sharma RK, Arora DS. 2013 - Fungal degradation of lignocellulosic residues: An aspect of improved nutritive quality. Crit. Rev. Microbiol. 16, 223.

Strobel G, Daisy B, Castillo U, Harper J. 2004 - Natural products from endophytic microorganisms. Journal of Natural Products 67, 257-268.

Ugwuanyi JO, Harvey LM, McNeil B. 2008 - Protein enrichment of corncob heteroxylan waste slurry by thermophilic aerobic digestion using Bacillus stearothermophilus. Bioresour Technol 99, 6974e85.

Valentino MJG, Kalaw SP, Galvez CT, Reyes RG. 2015 - Mycota of distillery yeast sludge as source of single cell protein. Mycosphere 6(3), 241-247.

Verma VC, Kharmar RN, Strobel GA. 2009 - Chemical and functional diversity of natural products from plant associated endophytic fungi. Natural Product Communications 4, 1511 $-1532$.

Yakoub Khan M, Umar Dahot M. 2010 - Effect of various agriculture wastes and pure sugars on the production of single cell protein by Penicillium expansum. World Applied Sciences Journal 8 (Special Issue of Biotechnology \& Genetic Engineering 80-84.

Zadrazil F. 1993 - Conversion of Lignocellulose waste into animal feed with White rots Fungi. Proceedings of the international conference of mushroom Biology. Pp. 55-116

Zafar S. 2015 - Agricultural wastes in the Philippines. Bioenergy Consult Powering Clean Energy Future. http://www.bioenergyconsult.com/agricultural-resources-in-philippines. 